\title{
What to Compensate? Some Surprisingly Unappreciated Reasons Why the Problem Is So Hard
}

\author{
LEO KATZ*
}

\section{TABLE OF CONTENTS}

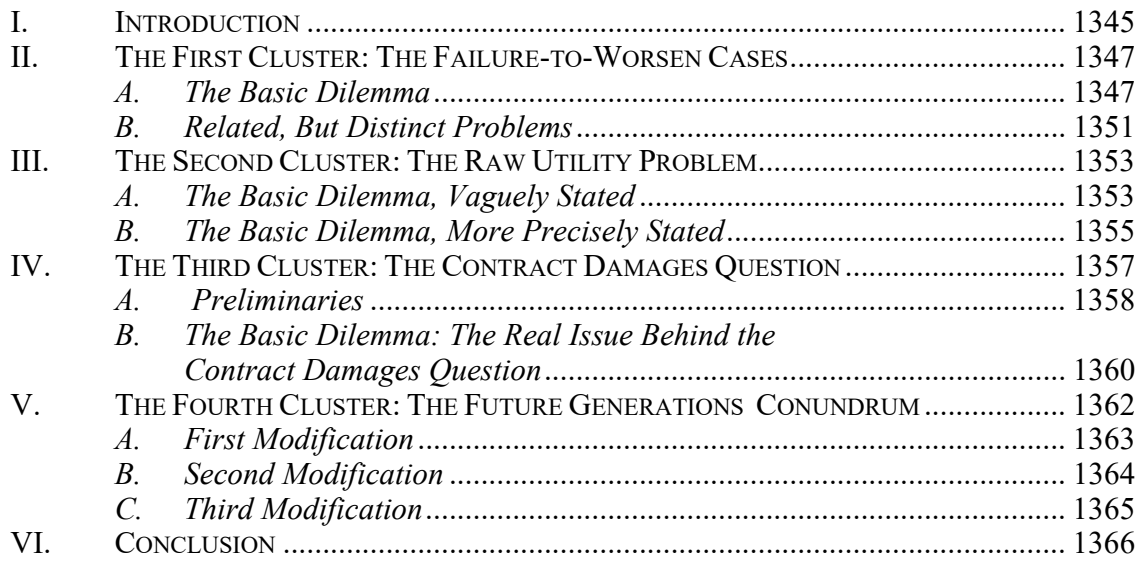

\section{INTRODUCTION}

Finding the rightful measure of compensation will typically require us to first choose an appropriate baseline. The baseline is how things would have gone for the plaintiff but for the defendant's actions. The difference

* Professor of Law, University of Pennsylvania. 
between how things would have gone and how they actually wentmore precisely, the difference between the plaintiff's baseline level of welfare and his actual level of welfare - is what we seek to compensate. Choosing that baseline is notoriously perplexing. Several of the most perplexing problems it gives rise to prompted this conference. Here is how they were laid out by the conference organizers:

Consider the plaintiff whose leg the defendant tortiously broke-thus preventing him from getting on the plane that crashed. Consider the plaintiff whom defendant tortiously fails to warn of high voltage wires, resulting in plaintiff's electrocution while - and a second before-falling to his death.

Consider the plaintiff whose loss of legs due to defendant's tortious conduct caused her to give up her career as a professional athlete-with the result that she is now much happier and has no regrets about losing her former career. Consider the plaintiff who, due to defendant's tortious conduct, is now much more churlish and psychologically unable to enjoy those things that give ordinary people pleasure.

Consider the promisee of an enforceable contractual promise asking to be put in the position he would have been in had the promise been kept.

Consider the plaintiff who but for defendant's tortious conduct would not exist. Consider the descendant of slaves who but for slavery would not have existed, and surely not in the United States. ${ }^{1}$

These problems seem to me to fall into four clusters: Indeed, I have slightly rearranged and reparagraphed the original letter so as to indicate what these four clusters are. My aim here will not be to solve the problem that each cluster raises, but rather to show what lies at the bottom of each. Their roots, it will turn out, are quite divergent. Baseline problems are not all traceable to one and the same fundamental difficulty. We will not be able to solve them until we appreciate the quite divergent sets of dilemmas that give rise to each of its various types. The four types of cases I will be considering each spring from a separate kind of dilemma. Laying those dilemmas bare-but not resolving them! - will be my aim here. Once that is done, I actually think that a suitable resolution may well be in sight, but I am not going to go that far. Here, the aim is simply to get to the bottom of what makes these compensation problems so hard.

1. Attachment to Letter from Larry A. Alexander, Heidi M. Hurd \& Michael S. Moore to invited participants in the conference Baselines and Counterfactuals in the Theory of Compensatory Damages: What Do Compensatory Damages Compensate? (Oct. 9, 2001) [hereinafter Letter from Larry A. Alexander] (on file with author). 


\title{
II. The FIRST Cluster: THE FAILURE-TO-WORSEN CASES
}

\begin{abstract}
Consider the plaintiff whose leg the defendant tortiously broke-thus preventing him from getting on the plane that crashed. Consider the plaintiff whom defendant tortiously fails to warn of high voltage wires, resulting in plaintiff's electrocution while - and a second before-falling to his death. ${ }^{2}$
\end{abstract}

\section{A. The Basic Dilemma}

In determining the victim's rightful measure of compensation, ought we to take account of the doomed plane ride, from which the plaintiff was deflected by being run into by the defendant's car and thus having his leg broken? In other words, should we include the doomed plane ride in the baseline against which the plaintiff's compensable harm is measured? If we do, we would not judge the defendant liable for anything, since running the car into the plaintiff prevented far worse. This is the "counterfactual" approach to harm: We ask whether, but for the defendant's actions, the plaintiff would be worse off and by how much; if, as here, the answer is that he would not be worse off at all, but on the contrary, better, the defendant avoids all liability.

But there seems at least one other plausible way of looking at the matter, which we might call the "causal" approach: We might ask what harm the defendant caused, which, in this case, would be the broken leg; that would then lead us to impose some significant liability. In other words, whereas the counterfactual approach allows us to net out the plane ride against the car crash, the causal approach does not.

The electrocution case, mentioned alongside the car crash case, is but a variation on this theme. To see this most clearly, it is worth transposing the electrocution case into the same factual setting as the car crash case. Suppose that the defendant's running his car into the plaintiff does not merely break the plaintiff's leg, but kills him. Again, however, suppose that if the victim had not been killed in the car crash, he would have been killed on the plane ride he was about to undertake. Once again, the question arises whether to net out the plane ride against the car crash. If we do, by adopting the counterfactual approach, then the only difference between this case and the previous one is that the netting out here leaves the plaintiff with a small, as opposed to zero, claim: the harm done him

2. Id. 
by accelerating his death ever so slightly. If we adopt the causal approach, then of course the defendant is fully liable for the plaintiff's death. I will, for the most part, concentrate on the first case (the nonfatal car crash) and leave it to the interested reader to extrapolate from that to the electrocution case.

Why should it be so hard to choose between what I called the counterfactual and the causal approaches? Why is it that each of these diametrically opposed approaches continues to seem so compelling, even after one has stared at them for a good long while? To get at what I take to be the heart of the problem, consider a slight variation of the car crash case. Suppose the defendant who crashes his car into the victim actually knows that he is thereby averting a greater harm. If he had such knowledge, it seems clear that we would net out the plane ride against the car crash. We would do so either by judging the defendant to have a necessity defense for the harm he inflicted or by judging him not to have inflicted a harm at all. That is, if the defendant knew, then the counterfactual approach would clearly be the right one. The question is whether anything should change if the defendant crashes his car into the plaintiff not knowing what good he is accomplishing thereby.

The issue here is virtually the same as one that has been the subject of a lively controversy in the criminal law: The defendant fires at his enemy, ignorant that the other is about to attack him, and he is therefore unknowingly acting in self-defense. Or, the defendant starts a fire, ignorant that another fire is already raging and that this one will serve as a nice firebreak; he is thereby unknowingly acting under necessity. One position taken with respect to these cases is that the defendant who does not know he has a defense is as blameworthy as the defendant who has no defense at all; he is guilty of murder and arson, respectively. Someone taking this position would presumably hold the car crasher liable for the victim's leg and ignore the averted plane ride. A second position taken with respect to these cases is that the defendant who does not know he has a defense is merely as blameworthy as someone who attempts a murder, or attempts arson, and fails. The justifying circumstances are in effect construed to be part of the definition of the crime. A murder is not simply an intentional killing; it is an intentional-killingwithout-a-defense. Therefore someone who kills intentionally, not realizing he has a defense, is attempting to kill-without-a-defense, but failing therein since he actually has a defense. Thus he is merely guilty of the attempt, not the completed offense. ${ }^{3}$

3. For major recent entries into the debate, see generally GEORGE P. FLETCHER, Basic CONCEPTS OF CRIMINAL LAW 101-06 (1998); Michael S. MOORE, ACT AND CRIME (1993); Russell Christopher, Self-Defense and Defense of Others, 27 PHIL. \& PuB. 
Noticing the connection between this debate and our own problem somewhat illuminates things, but I think still does not get us to the heart of the matter. Nor does it help us resolve the issue, since the criminal law controversy has so far remained unresolved.

However, the focus on the defendant who knows he is saving the victim's life by crashing his car into him proves to be a fruitful one-provided we combine it with another point, a very basic fact about tort and criminal law, whose full implications are often missed. Liability generally requires two things: wrongful means and harmful ends. The same harmful ends, if attained by rightful means, do not result in liability. This is just a more abstract-but, as it will turn out, helpful-way of saying that to be liable for someone's death, it is not enough that I have caused his death; I must have done so in a particular manner: typically, with a culpable state of mind (namely, intentionally, knowingly, recklessly, or negligently), via an act (as opposed to a mere omission), via a chain of events not deemed too circuitous (in other words, there must be proximate causation), and in the absence of a valid defense (like necessity or self-defense and the like).

Let us now consider the car crash scenario with these two points in mind: the point that the defendant would clearly not be liable if he had known, and the point that liability requires both wrongful means and harmful ends.

A wrongdoer, having produced a harmful end by wrongful means, might try to make the following argument: If I had attained those same ends by different means, I would not be liable. But then the only thing I should ultimately be liable for is my failure to choose those rightful means, instead of the wrongful means I did choose. Thus, in the car crash case, if I had brought about the same result (the broken leg) knowing that I was averting a worse catastrophe, I would not be liable. I would then have brought about a harmful end (the broken leg) by a rightful means, inasmuch as I would have run into the leg to avert worse. It is true that I did in fact bring it about by wrongful means, since I did not know what good I was accomplishing. But then all you are entitled to blame me for is the choice of those wrongful means-perhaps punish

AFF. 123 (1998); Anthony M. Dillof, Unraveling Unknowing Justification, 77 NOTRE DAME L. REV. 1547 (2002); Paul H. Robinson, Competing Theories of Justification: Deeds v. Reasons, in HARM AND CulPability 45 (A.P. Simester \& A.T.H. Smith eds., 1996); Paul H. Robinson, The Bomb Thief and the Theory of Justification Defenses, 8 CRIM. L.F. 387 (1997). 
me for some kind of criminal attempt — but what you cannot blame or hold me liable for is the harm I did.

When such an argument is first made, it might not sound all that convincing. Indeed one can quickly come up with examples that suggest that the argument is downright absurd. Just imagine someone who intentionally shoots his victim and then argues that if he had done the same thing inadvertently -in other words, by more "innocent" means - he would be deemed innocent. Therefore, he continues, he should only be blamed for reaching the harmful end of someone's death by the impermissible means of shooting him intentionally rather than inadvertently, but not for causing his death. Or, to illustrate the same point, imagine a rescuer who, recognizing that the person he has just rescued is someone he hates, throws him back into the sea to drown. We would not allow him to argue that since he could have brought about the same end, the victim's death, by alternative (but permissible!) means, namely by not rescuing him in the first place, the only thing he did wrong was to bring that end about by this particular wrongful means, and that, therefore, he should not be held liable for damages. Coming from the mouth of the shooter or the "rescuer," these arguments sound preposterous.

And yet the preposterous sounding argument has more power to it than first appears. Suppose you foresee inflicting a harm by one or another means, some permissible, some impermissible. By incurring a certain expenditure in either money or effort or risk, you can make sure that the harm eventuates by a permissible, rather than an impermissible, means. Ought you to undertake that expenditure? Not if it is at all substantial. It seems quite clear that you should not go to great lengths to ensure that the victim is killed by a letting-die rather than a rescue-followed-by-anactive-killing, or that he is run over accidentally rather than intentionally, or that the car is crashed into him with knowledge that the perpetrator is thereby averting a worse catastrophe rather than without such knowledge. But if such an expenditure is not in fact called for, then how can we impose substantial liability for harm when it is not undertaken?

Let me spell this last point out more fully, so that its force can be better appreciated. Suppose the car crashing defendant argued as follows: I enjoy taking risks. Indeed, I enjoy being downright reckless. Needless to say, I do not enjoy being held liable. If I will only be credited with the good consequences of my actions (like that averted plane ride) when I actually foresee them, I will henceforth investigate every risk-taking venture in which I engage more thoroughly, so as to become more fully aware of possible favorable consequences. I will not alter my course of action one iota in light of this information. But I will now act in greater awareness of the good, as opposed to the harmful, effects my risky 
conduct might occasionally produce. Such an investigation, had I conducted it, would in this case have led me to conclude that the plane the plaintiff was about to board faced a serious danger of mishap. Do you really think I deserve to be held liable for not undertaking such efforts and expenditures when they could not possibly have affected my actions? ${ }^{4}$

This strikes me as a very hard-to-answer argument. And yet, if we accept it, it seems we would also have to accept the argument of the ordinary murderer who says that if he had done what he did with an innocent state of mind, he would not be guilty of murder, but merely an accidental killing. ${ }^{5}$ And that seems very hard to accept indeed. The hard-to-answer argument and the hard-to-accept argument are the two horns of the dilemma that I believe lies at the heart of the failure-toworsen cases.

\section{B. Related, But Distinct Problems}

My analysis so far has proceeded on the basis of two unstated assumptions which I should make explicit and defend.

4. Someone might try to get around this argument by arguing that only the defendant who is not merely aware of, but motivated by, the good consequences of his actions should get a break. But neither this nor a host of possible variations on this objection are likely to work. For each one could construct a case analogous to the one given to make the same point.

5. It might seem tempting to argue that the case of the ordinary murderer is different from all the others because one cannot arrange it, through careful planning and extensive expenditures, that one will kill inadvertently rather than intentionally. But that is not true. Often, one will be able to turn an intentional killing into an inadvertent one through sufficiently careful planning. An example I have used previously would work as follows: Suppose defendant has taken out life insurance in the name of his son. He then plans to set fire to his house, in the course of which he hopes his son will die. To cover his tracks, he will do his darndest to try to save his son, once the fire has been started, but given the devastating nature of the conflagration he thinks that there is only about a forty percent chance that this rescue will succeed. In other words, there is a sixty percent chance that his son will die. At the last minute he has an idea for limiting his liability, in case he is discovered. He changes the insurance policy to be triggered, not by the death of his son, but by the destruction of the house. He keeps every other part of his original plan intact. If under these circumstances his son dies - of which there is a sixty percent chance - the defendant will only be guilty of manslaughter.

The death, if it occurs, will only have occurred as a byproduct of his plan to get the insurance money, rather than as a means toward that end; thus he will only have caused the death recklessly, rather than intentionally. If we lower the son's probability of death even further, he might not even qualify for that level of liability. For a fuller discussion of this case and cases like it, see LEO KATZ, ILl-GotTEN GAINS: EVASION, BLACKMAIL, FRAUD, AND KindRED PUZZLES OF THE LAW 1-131 (1996). 
When I asked us to consider the case in which the defendant knows that by crashing his car into the plaintiff he is saving him from a doomed plane ride, I was tacitly assuming that this was the only way the defendant had of saving the plaintiff. That is an admittedly unrealistic assumption, but it was necessary to bypass a distracting difficulty that is not really part of the basic dilemma the case raises. Suppose we had proceeded on the more realistic assumption that the defendant has other, less injurious means available for saving the plaintiff and knows that he does. Now it will be a very puzzling matter to decide whether his saving the plaintiff from a worse fate still exonerates him. By its terms, the necessity defense only entitles one to commit wrongs that are necessary: Breaking the plaintiff's leg is not, strictly speaking, necessary to save him. And even putting aside this narrow doctrinal argument, it would seem as though granting the defendant a necessity defense, when he could have averted the calamity by much less injurious means, would lead to some highly peculiar consequences. The philosopher Shelly Kagan, in a different context, offers the example of someone who saves a choking victim by applying the Heimlich maneuver, but who simultaneously stabs the victim in the thigh. ${ }^{6}$ (Why? For no good reason, just for the hell of it.) Would we forgive the stabbing because it accompanied the Heimlich maneuver? Probably not. But are we not doing the same thing when we grant the necessity defense to the defendant in the car crash case, when there are less injurious means available for saving the plaintiff? Possibly. But does that really mean we should hold him liable? After all, there remains the hard-toignore fact that the defendant's running the car into the plaintiff is a vast improvement on just letting him board the plane. It is this sideissue - what to do about a defendant who chooses the lesser, but not the least of several evils - which I tried to bypass by assuming that the defendant's only recourse for saving the plaintiff was to crash the car into him.

My second unstated assumption is a little harder to convey. Imagine the car crash case had unfolded in a slightly different way than we have been imagining so far. Let's take the doomed plane ride out of it, but add another feature to the case instead. Suppose that quite soon after the plaintiff has been injured, his wounds, although they initially appeared very serious, heal up completely, leaving behind no residual ill effects. In this case, of course it is quite clear that the plaintiff would not be entitled to any damages whatsoever. The beneficial developments subsequent to the injury completely neutralize the harmful actions of the

6. Shelly Kagan, The Limits of Morality 97 (1989). 
defendant. ${ }^{7}$ Now one might ask whether the avoidance of the doomed plane ride could not be viewed in the same way, as a beneficial development that completely neutralizes the harmful actions of the defendant. Very abstractly put, it could indeed. But it also seems quite clear that we treat differently "neutralizing" beneficial developments that follow closely on the heels of the original harmful acts, both temporally and physically, as well as being similar, both quantitatively and qualitatively, to the harm they neutralize. I assumed the plane ride case not to be of this variety. Otherwise my analysis could, of course, have been far simpler.

\title{
III. The SeCond Cluster: The RAW Utility PROBLeM
}

\begin{abstract}
Consider the plaintiff whose loss of legs due to defendant's tortious conduct caused her to give up her career as a professional athlete-with the result that she is now much happier and has no regrets about losing her former career. Consider the plaintiff who, due to defendant's tortious conduct, is now much more churlish and psychologically unable to enjoy those things that give ordinary people pleasure. ${ }^{8}$
\end{abstract}

\section{A. The Basic Dilemma, Vaguely Stated}

Two people suffer an accident. Both have their careers derailed. Both end up having to make new lives for themselves. The first ends up much happier for the experience, fate having tossed her into a direction much more congenial to her; the second ends up miserable, fate having deflected her from the best possible life for her. Is it anything other than self-evident that the first person has been harmed less than the second? And that if there is a culprit behind each of the accidents, he ought to pay more for the greater harm he did in the second than in the first case? Yet most of the law conflicts with such common sense.

Raw utility, happiness pure and simple, counts for surprisingly little in the law. Tax law is in some ways the most glaring and paradoxical-seeming example of this. Two people derive equal amounts of happiness from life. One does so by earning a high income and then spending it on things that generate a great deal of utility for him. Another does so by earning a very small income and getting lots of nonpecuniary satisfactions from his ill-paid job. Those nonpecuniary benefits are not

7. Anthony Dillof puts this distinction to extremely interesting use in his analysis. See Dillof, supra note 3, at 1549.

8. Letter from Larry A. Alexander, supra note 1. 
taxed. That strikes many people as strange: Both work to produce the utility necessary for a happy life. They do so in slightly different ways. And the law treats them radically differently. Why would the law reward someone just for being lucky enough to be able to achieve happiness without going through the intermediate process of first earning money to buy it? The conventional answer is that it is too impractical to try to tax all nonpecuniary benefits. We tax such benefits when we can: when they are discrete and easily valued, like the use of a company car, or a company apartment, or a company-financed education for one's children. And we do not tax them when we cannot: when they are amorphous and hard to quantify, like the collegiality of one's colleagues, or the prestige that goes with a certain line of work. But the conventional wisdom seems doubtful. More likely, we do not tax most nonpecuniary benefits because the logical implication of doing so would be to say that a wealthy but unhappy CEO should be taxed less than a blissfully happy mendicant monk who earns his keep by begging. It is not that we are trying to encourage people to become mendicant monks. We just do not view their extra utility as grounds for putting an extra tax burden on them.

Raw utility also does not count for much with most doctrines in criminal and tort law. Suppose a defendant were to argue that the enormous risk he imposed on others as he sped to his job interview was justified by the enormous utility he would derive from having a successful interview. His utility counts for nothing. Rather, we say that the job interview entitles him to impose a risk of a certain amount on others, and no more, quite regardless of his personal feelings in the matter. Or suppose a defendant were to argue that the lethal force he used to defend his property was justified because he valued his property more dearly than his person, and whatever self-defense would ordinarily be permitted in defense of one's person, he should be permitted to use in defense of his property instead. Once again his utility counts for little. Rather, we say that the defense of his property entitles him to the use of a certain amount of force, and no more, quite regardless of his feelings in the matter. Or suppose a defendant were to argue that the crime he committed because he was threatened with the destruction of his prized book manuscript should be excused on grounds of duress (even though such a serious crime would ordinarily only be excused if he had faced a threat to life and limb) because, he says, this manuscript was dearer to him than either life or limb. Once again we would take no account of his utility. Rather, we would say that the protection of his manuscript simply does not entitle him to the kind of indulgence we would grant if he were trying to preserve life or limb. ${ }^{9}$

9. We have here but a manifestation of a phenomenon Thomas Scanlon drew attention 


\section{B. The Basic Dilemma, More Precisely Stated}

So far, what I have said simply suggests a very general tension between one's common sense reaction to the original example of the tort victim and the way the law treats gains and losses of raw utility. But the tension, and the paradoxes it raises, can be made far more precise. Let us elaborate somewhat on our original example. The car crash victim and aspiring athlete, having had her leg broken, is brought to the emergency room. She already realizes, let us suppose, that, in the end, this accident is actually going to make her life better rather than worse: It will allow her to escape from a variety of commitments she has made for what she had already concluded was going to be a very unhappy life as a professional athlete. Now, as it happens, the injury to her leg is not the only one she suffered. She also did some slight damage to one of her pinkies. She is a passionate hobby pianist and is greatly worried that even slight but permanent damage to her pinkie might interfere with this avocation. Consequently, when she arrives at the emergency room, she immediately asks the doctor to attend to her pinkie rather than her leg. The doctor is ready to do as she asks him, but then another patient is wheeled into the emergency room. This one has a somewhat damaged arm - an injury, let us say, halfway in severity between a broken leg and a damaged pinkie. Whom should the doctor attend to first?

As between the arm and the pinkie, it seems clear the doctor should attend to the arm first. That is what the law would require: The damage to the arm is a more serious matter than the damage to the pinkie. Therefore, that patient has a greater claim to the doctor's attention. If the doctor fails to attend to him first, he is negligent. Moreover, the law here seems to mirror our moral judgment in the matter.

All right, so the doctor turns away from the pinkie and to the second patient's arm.

But is that in fact what he should be doing? There is a third injury in the picture we have so far not taken account of. Is it not clear that, as between the second patient's arm and the first patient's broken leg, the broken leg deserves priority? A broken leg seems a more serious matter than a damaged arm (or so we stipulated, anyway). Therefore, that

to in a famous essay, Preference and Urgency. T.M. Scanlon, Preference and Urgency, 72 J. PHIL. 655 (1975). "The fact that someone would be willing to forego a decent diet in order to build a monument to his god does not mean that his claim on others for aid in his project has the same strength as a claim for aid in obtaining enough to eat ...." Id. at $659-60$. 
patient has a greater claim to the doctor's attention, and if the doctor fails to attend to her first, he is negligent. In this too the law seems to mirror our moral judgment.

Fine, so let us have the doctor turn away from the arm and toward the first patient's leg.

At this point, however, the first patient protests: She says she would much rather have the doctor treat her pinkie than her leg. She points out that she would be suffering a far more severe harm if she lost the use of her pinkie than the loss of her leg: After all, the loss of the leg would chiefly have the effect of derailing her athletic career, and that is more than counterbalanced by the increased happiness she can expect from that. So should the doctor acquiesce in her wish?

Now the doctor finds himself in a cycle: The arm beats out the pinkie; the leg beats out the arm; the pinkie beats out the leg, and the arm beats out the pinkie. The cycle results from combining the common sense position that the derailed athlete's increased happiness should be netted out against losses with the law's position that one's claims under the negligence doctrine are not dependent on one's subjective valuation of those claims. Breaking the cycle requires giving up on one of these two eminently plausible positions. ${ }^{10}$

10. The particular way in which I just illustrated the tension between the common sense position and that of the law is not the only way of dramatizing the conflict. Here is another, which builds on some very startling, recent work by Robert Cooter and Ariel Porat, and raises what I have come to call the Cooter-Porat paradox. (They do not quite think of it as a paradox, but here their modesty got in the way of their analysis.) See Robert Cooter \& Ariel Porat, Does Risk to Oneself Increase the Care Owed to Others? Law and Economics in Conflict, 29 J. Legal StUD. 19 (2000). In their article, they ask us to consider the following case:

John discovers that the buckle on his seat belt is broken. Buckling it is impossible. No statute requires drivers to wear seat belts. The speed limit is 30 miles per hour. Time is very valuable to John this morning, so he decides to drive unbuckled. John drives 30 miles per hour, his car skids, and he hits Tony's parked car. If John had driven 25 miles per hour, then he would have avoided hitting Tony's car. Considering John's risk to himself and John's risk to Tony's car, the reasonable speed to drive was 25 miles per hour. Considering only John's risk to Tony's car, the reasonable speed to drive was 30 miles per hour. The rule of law is negligence. In a suit for damages by Tony, should the court find John liable?

Id. at 19-20. They note the following:

In conventional legal applications of the Hand Rule [of negligence], courts balance the burden of precaution to the injurer and the risk of harm to the victim. In this example, the court would not admit evidence on the broken seat belt. Risk to the injurer is treated as irrelevant to his legal liability.

$I d$. at 20. It is hard to see how anyone could quarrel with the courts' position: Of course the courts would not admit such evidence! Why should they? What does the defendant's nonfunctional seat belt have to do with the price of tea in China? What matters is whether the defendant was negligent toward his victim, not whether he was, as it were, "negligent" toward himself, an already absurd notion. The defendant's seat belt use is a matter of total irrelevance.

Wrong, say Cooter and Porat, the defendant's seat belt is highly relevant to the issue of 


\author{
Therein, I believe, lies the central dilemma raised by the "raw utility" \\ cases. ${ }^{11}$
}

\title{
IV. THE THIRD Cluster: THE CONTRACT DAMAgES Question
}

Consider the promisee of an enforceable contractual promise asking to be put in the position he would have been in had the promise been kept. ${ }^{12}$

negligence. $I d$. at 22-25. Think about it this way, their ingenious argument runs: Because of the broken seat belt, the defendant's cost of slowing down has dropped! It has dropped because that cost has two components, a positive and a negative one. The positive component is whatever disadvantage accrues to the defendant from slowing down. The negative component is the increased safety he derives from slowing down. In other words, his total cost is the difference between the safety benefit from slowing down and the disadvantage from arriving at his destination a little later. Because his seat belt is broken, the negative component - the increased safety from slowing down - is larger than it would otherwise be. As a result, the cost to him of slowing down is less than for someone with functional seat belts. Thus, surprisingly enough, the seat belts really do matter to our assessment of negligence. Id.

As I said, Cooter and Porat do not present their argument as a paradox. They present it as a correction of what they perceive as a common mistake in assessing negligence. Id. at 25-28. The reason I think that what they have uncovered is a paradox is that the argument for disregarding the defendant's seat belt use is considerably stronger than they acknowledge. What supports the courts' refusal to take self-risk into account is nothing less than the Pareto principle, and in urging their "correction," Cooter and Porat are violating the Pareto principle. That does not mean that they are wrong. I do not view the Pareto principle as sacrosanct. But it does mean that the arguments on both sides of the issue are quite balanced, which is why we have a paradox. I will explain this more fully in Leo Katz, Choice, Consent and Cycling - Why Our Desires Count for So Little in the Criminal and Tort Law and Why That Can Probably Not Be Helped (unpublished manuscript, on file with author).

Now let us connect the Cooter-Porat paradox with the problem at hand-whether to take into account the increased happiness experienced by the athlete with the broken leg. Suppose our would-be athlete is thinking about whether to take a certain precaution while engaging in a risky activity. Specifically, let us assume that the activity carries only one risk for him, that of breaking his leg. Taking the precaution would reduce both the risk to bystanders and the risk to his own leg. But, of course, he does not much value that last bit of risk reduction. The Cooter-Porat argument tells us that that is irrelevant. The reduction in the risk to his leg should nonetheless be taken into account in determining whether he was negligent. See Cooter \& Porat, supra, at 31-32. In other words, the benefit he derives from having his leg broken should be ignored. Of course the CooterPorat argument is just one side of a paradox. So it ultimately is not clear whether his benefit from having his leg broken should count. The Cooter-Porat paradox thus turns out to be just another manifestation of what I called the "raw utility problem."

11. I first introduced an example like this one in KATZ, supra note 5, at 53-55. I explore its ramifications more fully in a work in progress. See Katz, supra note 10.

12. Letter from Larry A. Alexander, supra note 1. 


\section{A. Preliminaries}

Everybody understands that there is a problem about contract damages. The above-quoted case is really just a somewhat elliptical statement of it. Douglas Laycock's casebook, Remedies, offers a less elliptical statement: "[T]he fundamental principle of damages is to restore the injured party as nearly as possible to the position he would have been in but for the wrong ..., '[his] rightful position' ...." $\mathrm{He}$ goes on to explain:

As you undoubtedly learned in first-year contracts, the victim of a breach of contract is entitled to recover the profits he would have earned if the contract had been performed. But it is not obvious that that should be the remedy.... In remedies terms, the question is what we mean by rightful position: the position plaintiff occupied before he made the contract, or the position he would have occupied if the contract had been performed? ${ }^{13}$

In terms of baselines, the question is why the baseline for measuring contract damages is "the position plaintiff occupied before he made the contract"- the "reliance measure"-rather than the position he would have occupied if the contract had been performed-the "expectations measure." Fuller and Perdue, in their classic article on the subject, The Reliance Interest in Contract Damages, toy with, but are ultimately not quite satisfied with, a sort of psychological explanation. In response to the question, "Why should the law ever protect the expectation interest?," Fuller and Purdue say the following:

Perhaps the most obvious answer to this question is one which we may label "psychological".... The breach of a promise arouses in the promisee a sense of injury. This feeling is not confined to cases where the promisee has relied on the promise. Whether or not he has actually changed his position because of the promise, the promisee has formed an attitude of expectancy such that a breach of the promise causes him to feel that he has been "deprived" of something which was "his". Since this sentiment is a relatively uniform one, the law has no occasion to go back of it. It accepts it as a datum and builds its rule about it.

The difficulty with this explanation is that the law does in fact go back of the sense of injury which the breach of a promise engenders. No legal system attempts to invest with juristic sanction all promises. Some rule or combination of rules effects a sifting out for enforcement of those promises deemed important enough to society to justify the law's concern with them. Whatever the principles which control this sifting out process may be, they are not convertible into terms of the degree of resentment which the breach of a particular kind of promise arouses. Therefore, though it may be assumed that the impulse to assuage disappointment is one shared by those who make and influence the law, this impulse can hardly be regarded as the key which solves the whole problem of the protection accorded by the law to the expectation interest. ${ }^{14}$

13. Douglas Laycock, Modern American Remedies 14-15, 22 (1st ed. 1985).

14. L.L. Fuller \& William R. Perdue, Jr., The Reliance Interest in Contract Damages: 
More recently, Richard Posner, in an early application of economic analysis to law, has suggested that expectations damages are more efficient than reliance damages because they lead the breaching party to take into account the full value of the cost he is imposing on the aggrieved party. ${ }^{15}$ Not everyone has been convinced. After all, there are two ways of describing cost in this case-the reliance version and the expectation version - and the reliance version is considered pretty efficient when it comes to torts. Just exactly why would it not be suitable for contracts as well? ${ }^{16}$

And then there are some who deny that there is any problem at all. In an approach dating back to Aquinas and Grotius, and more recently advocated by Randy Barnett, the following way of looking at the matter has been put forward. ${ }^{17}$ Consider by way of analogy a case we have considered before: The defendant gratuitously confers some benefit to the plaintiff - say, by rescuing him from drowning or from the prospect of some other kind of injury to his person or his property. Having successfully completed the rescue, the defendant subsequently inflicts some harm on the very things he saved: He throws the drowning victim back into the water, or hurts him in some other way, or destroys some of the goods he prevented from being damaged in the first place. Here too there are two possible baselines one might use for measuring his damages. One could ask the defendant to restore the plaintiff to the position he would be in if the defendant had never undertaken to do anything for him in the first place - this is the analogue to the reliance measure. Or one could ask the defendant to restore the plaintiff to the position he would be in if the defendant had not performed any harmful actions subsequent to the rescue - this is the analogue to the expectations measure. Now in this case we are relatively clear that the latter measure is the only proper one. Why then, ask Grotius and Aquinas and Barnett, should we not say exactly the same thing about the contracts case? Why not view the promisor's promise as transferring something out of the possession of the defendant into the hands of the plaintiff, and then treat the breach of the promise as inflicting a harm by retrieving it, much as

1, 46 YALE L.J. 52, 57-58 (1936) (footnotes omitted).

15. RichARD A. POSNER, ECONOMIC ANALYSIS OF LAW 108-11 (3d ed. 1986).

16. For more on the shortcomings of this explanation, see Richard Craswell's contribution to this symposium. Richard Craswell, Instrumental Theories of Compensation: A Survey, 40 SAN DIEGO L. ReV. 1135 (2003).

17. Peter Benson, Contract, in A Companion to Philosophy of LAW AND Legal Theory 24, 40-43 (Dennis Patterson ed., 1996). 
we treat throwing someone who has been saved back into the water as a harm, despite the fact that the victim is no worse off than if he had never been saved in the first place?

I do not agree with Aquinas and Grotius and Barnett that there is no real problem concerning contract damages. Rather, I think, like Laycock, Fuller, Perdue, and Posner, that there is something here crying out to be explained. But the analogy used by Aquinas, Grotius, and Barnett makes it clear, I think, that the problem is a little different from what it is usually understood to be. Let me go on, then, to explain what I think the real problem of expectation damages is.

\section{B. The Basic Dilemma: The Real Issue Behind the Contract Damages Question}

It is an ill-understood fact that not all legal and moral entitlements are equal in strength. One measure of the strength of an entitlement is what you can do to protect yourself against its infringement and what you can do to get vindication from a successful infringement. By this measure, your strongest entitlement is to the physical integrity of your person and of your property. If someone tries to harm you, or what is yours, you can resist him with force, and you can demand full compensation for any losses you incur.

By the same measure, you have a somewhat weaker entitlement not to be subject to certain nonphysical attacks against yourself or what is yours. If someone slanders you, or seeks to alienate the affections of your spouse, or intentionally inflicts emotional distress, to name just the best-established of the nonphysical torts, you are no longer permitted to use force as a means of self-help. For the most part, your only recourse is to seek compensation in the courts.

It is important to note something easily overlooked about the concept of the "strength" of an entitlement. It has nothing to do with the monetary value of the entitlement. An injury to your body may be far less serious than an injury to your reputation, in terms of the dollar amount of compensation you are due, despite the fact that the former infringes a much more serious entitlement than the latter.

There is, I believe, yet a weaker kind of entitlement than the two mentioned so far, although its existence has rarely been clearly acknowledged in legal scholarship. Consider the following: $D$ cheats on some law school exams, thereby disadvantaging his classmates. In a subsequent job interview, $D$ ends up going toe-to-toe with $V$, one of those classmates. $D$ gets the job ahead of $V$, because of his slightly better grades in the courses in which he cheated. Could $V$ bring a suit against $D$ seeking to demonstrate that $D$ cheated and should compensate 
$V$ for the lost job opportunity? It is clear that $D$ committed a wrong, and it is also clear that the wrong caused harm to $V$, quite possibly greater harm than a more traditional crime or tort might have. Nevertheless we would be extremely reluctant to grant $D$ a cause of action. The entitlement $V$ would be seeking to vindicate just seems too ethereal.

If one has not previously considered the possibility of this kind of case, it might seem as though this example is bound to be a very peculiar and isolated one. But it is not. Here is another example of a similarly weak entitlement: $D$ lives in a state with a duty-to-rescue statute, like Vermont's: Anytime a bystander can easily save someone from certain death, he is required to do so. The statute imposes a small fine on those who fail to heed this duty. Now suppose that $D$ sees someone who is in the process of drowning; he could easily rescue him, yet fails to do so. He clearly falls within the Vermont statute. Is he liable for murder, or wrongful death? Black letter law tells us that a defendant who fails to heed a statutory duty and thereby causes death is as guilty as if he had caused death by an act. The implicit assumption seems to be that the statute creates an entitlement, analogous to a property right, and if that entitlement is not honored, this is the equivalent of invading a property right and causing a death thereby. Yet it seems doubtful that in fact all statutory duties can serve as the triggers for such homicide liability. It seems doubtful that the Vermont statute would be so viewed. The entitlement it creates quite simply seems too flimsy.

Here is a final example in the same vein. $D$ sends a check to $V$, which will save $V$ 's life. Having deposited the envelope containing the check in the mail box, $D$ changes his mind. He breaks into, and thereby damages, the mailbox and retrieves the envelope. $D$ committed a wrong. $V$ of course is the most adversely affected party of $D$ 's actions. An interest of his has been invaded, inasmuch as he could expect that in the ordinary course of events the check would reach him, and only a wrongful action by someone else, namely $D$, prevented him from actually receiving it. Nonetheless, we would be reluctant, I think, to allow $V$ to be compensated. $V$ 's entitlement to that check-namely that he would have gotten it but for the unlawful efforts by $D$ to retrieve it-just seems too weak. ${ }^{18}$

Let us now look into the entitlements created by a contract. The aggrieved party who is worse off than he would have been if the

18. Many cases in which an unambuously adversely affected plaintiff is said to lack standing, or the statute that he invokes is said not to have created a private cause of action, are in fact cases of this weak-entitlement ilk. 
defendant had never made him a promise in the first place (in other words, the plaintiff who is seeking his reliance damages) is much in the same position as a tort claimant seeking vindication for a nonphysical tort, like slander, or alienation of affections, or the intentional infliction of emotional distress. His entitlement intuitively appears to be of a strength that would justify full compensation, but not quite strong enough to justify using physical force to defend it, the way he might defend his property or his person. But what about the aggrieved party who seeks vindication for his expectation damages? The expectation entitlement seems a good deal more ethereal than the entitlement not to be subjected to slander, or alienation of affections, or the intentional infliction of emotional distress. Is it so ethereal as to rank with the case of the disadvantaged law student, or the unrescued drowning victim in Vermont, or the unsuccessful check recipient? It is here, to my mind, that the central issue raised by the contract damage question lies. We hesitate about expectation damages because we are not sure that the expectations-based entitlement (as opposed to the reliance-based entitlement) created by the contract ranks close enough to the entitlement created by nonphysical torts to warrant compensation. We can also now see why the analogy used by Aquinas, Grotius, and Barnett will not really work: A contract claim is something substantially less sturdy than the transfer of a property right, and an infringed contract claim is something substantially less serious than an infringed-upon property right. Whether it is so much less serious that it should not be vindicated in court is the real contract damage question.

\section{THE FOURTH CLUSTER: THE FUtURE GENERATIONS CONUNDRUM}

Consider the plaintiff who but for defendant's tortious conduct would not exist. Consider the descendant of slaves who but for slavery would not have existed, and surely not in the United States. ${ }^{19}$

The slavery reparations question represents, I believe, the convergence of at least three basic dilemmas. The best way to get at them is to view the slavery reparations question, large as it is, as part of an even larger category - that of all cases involving plaintiffs who but for the defendant's tortious conduct would not exist.

Let us begin by considering an exceedingly simple instance of such a case. Suppose $D$ rapes $V$. $V$ has a child. Does $V$ have a claim for compensatory harm? The rape victim of course does, but does the child? It is hard to see reasons why it would. To be sure, it might have a claim

19. Letter from Larry A. Alexander, supra note 1. 
in behalf of its parents' estate. But that is different. Does that mean that the descendants of slaves who but for slavery would not have existed do not have a claim either, at least not a claim in their own (as opposed to their parents') behalf? No, it does not. The rape example fails to incorporate a number of features arguably crucial for the slavery case. Let us try to add such features to our rape example.

Now I should immediately point out that I will not be striving to take account of certain features of the slavery question that are not particularly connected to issues of harm: the fact that such claims today can only be made against the descendants of the tortfeasors rather than the tortfeasors themselves, or even their estates, that they would have to be made against the government rather than individuals, that so much time has passed since the tort occurred, that many descendants of slaves are also the descendants of slave-owners, and numerous other such collateral complications. The kind of claim I shall be imagining is one brought by the children of slaves against the actual slave-takers and owners or their estates.

I shall proceed by gradually modifying the original rape case in a way that brings it arguably closer to the slavery case.

\section{A. First Modification}

Clearly, one thing that is missing from the rape case is some of what is usually captured by the reference to the lasting, generation-transcending effects of slavery. Consider then the following variation of the rape case. Let's assume the rapist infects his victim with a disease, and the victim then transmits the disease to her child. Now does the victim's offspring have a persuasive claim? This turns out to be a remarkably thorny question.

On the one hand, it seems as though the child has a rather clear-cut claim: There is a fairly direct causal route that connects the defendant's wrongdoing with the harmful consequences to the child.

On the other hand, we now run into what Derek Parfit has called the "nonidentity problem." 20 Despite the causal chain connecting the defendant's actions with someone else's harm, there is the following very basic fact casting grave doubt on the victim's claim: The plaintiff is unable to argue that but for the defendant's wrongdoing, he would be better offsince but for the defendant's wrongdoing he would not exist at all.

Which of these two ways of thinking about the child's claim is the

20. Derek PARfit, ReAsons AND PERSONS 351-80 (1984). 
more persuasive? Unfortunately each has some rather hard-to-swallow implications. Let us consider more closely the first view, holding that since the defendant directly caused the child's illness, he should be liable. Consider now the case of a woman who decides to have a child, even though she knows that she has a genetic disease which she might transmit to it. If we say the rapist is liable because he caused the child's illness, it would seem we would then also have to say that that woman is liable as well, since she too is connected by a direct causal chain to the illness of her child. That seems very counterintuitive.

Let us consider more closely now the alternative view, which would preclude liability on the ground that the child cannot say that but for the defendant's actions it would be better off (since it would not exist at all). If we follow this view to its full logical conclusion, we would have to say that no generation can ever complain about having been harmed by a past generation. Conversely, no present generation need ever worry about the impact of its actions on some distant future generation. The reason is that future people will never be in a position to argue that they would have been better off but for the wrongful actions of their forbears. Had their forbears not behaved wrongfully, they would, incidentally, have produced different people, by procreating at different times and bringing slightly different sperm together with slightly different eggs. Those future people would then in fact have been better off than the complainants, but the complainants themselves would not. This too seems like a very counterintuitive conclusion.

This I take to be one of the basic dilemmas underlying the slavery question - the excruciatingly difficult choice between these two counterintuitive implications: Either we are forced to blame (and impose liability on) a mother who, despite having a genetically transmissible disease, decides to have a child, or in the alternative, we are relieved of ever worrying about the impact of anything we do on future generations.

\section{B. Second Modification}

Let us, for the time being, assume that we are ultimately persuaded to seize the horn of the above dilemma that allows us to impose liability on the rapist and on the slave-takers (and their estates) for harm resulting to their victims' descendants. One arguably relevant feature we have left out of our analysis so far are the blessings of living in the United States. Let us try to modify the rape example so as to incorporate such a feature. Here is one way to do it: Suppose that, along with the infectious disease, the child also acquires rights to the rapist-father's very substantial inheritance, an inheritance that is far larger than the harm of which the child complains. It seems not implausible to argue that the complained- 
about harm should be netted out against the inheritance and that therefore the child might not be entitled to any compensation after all.

But let us pause to consider whether the inheritance is in fact the right way to "model" the blessings element. Suppose the rapist-father has no assets to bestow, but there is a distant relative, who has designated certain biological relatives, like the plaintiff, as the beneficiaries under his will. Now it seems a lot less plausible that the inheritance should be offset against the harm. Should the blessings of living in the United States perhaps be viewed in this way rather than the other?

There is a yet a third way in which we could have tried to model the blessings element. We could replace the inheritance with an altogether different kind of asset. We could imagine that the rapist-father has genes for a particularly long and healthy life. In combination with the infectious disease, the child can therefore expect to live a life of normal length and health. Now it suddenly seems extremely plausible to net out the blessings against the harm.

Here then lies the second dilemma of the slavery case: Different analogies pull us into vastly different directions on the question of which benefits of living in the United States should be netted out against the harms that continue to haunt the descendants of slaves.

\section{Third Modification}

Let us continue to suppose the rape victim's infected child has been awarded compensation - in other words, that the liability-creating perspective has prevailed. Indeed, let us assume that the award has been in no way diminished by any offsetting collateral benefits. Suppose now that the rape victim's child, in turn, has a child of its own, to whom this same infection gets transmitted. Does that second generation offspring have a claim against the rapist? Again, two diametrically opposing perspectives on the matter present themselves.

On the one hand, one might argue that, compensation having been paid once, all further liability is extinguished. Once a tort has been compensated, it has in effect been undone. It is as though the rape had never occurred. If we view things that way, then the second generation offspring no longer have any claim. The defendant has compensated the rape victim and her immediate descendant for the immediate harm they suffered as well as the diminished chance of having healthy children down the road. From here on out, he is no more responsible to the second generation offspring than he would be to anyone else whose parents decided to 
throw caution to the wind and create a child with congenital problems.

On the other hand, one might say that any compensation paid the rape victim and her direct descendant only covers the harm they suffered. The defendant by his tortious actions has inaugurated a harmful sequence of events that is continuing on its way through the generations, and the second generation offspring are simply its most recent victims. They are no less entitled to compensation than the first generation offspring. To be sure, the first generation offspring was the one who ultimately made the decision to bear a child, and one might thus wonder whether that decision might not break the chain of proximate causation. But the decision to have a child would probably not be viewed as sufficiently "voluntary" to break the chain, since it would seem rather unreasonable to expect someone to just give up on the possibility of parenthood.

This is the third dilemma raised by the slavery question. If reparations are in fact paid to slave descendants, would those or would those not extinguish the claims of future descendants? Two seemingly equally plausible but incompatible answers have suggested themselves.

\section{CONCLUSION}

This Essay took up four quite intractable compensation problems and tried to show what has made them so intractable. Although all four types of problems can be described as posing a question about baselines, they do so in extremely different ways.

Failure-to-worsen cases are difficult because they seem to require us to choose between giving no weight to the particular way in which a harm is produced, or in the alternative, viewing it as beneficial if a defendant expends great effort to make sure he inflicts a certain harm in one way rather than another.

The raw utility problem is difficult because it seems to require us to choose between not treating a loss of utility as a harm, or in the alternative, allowing someone to argue he was not negligent because of the enormous personal weight he attached to the purpose for which he was creating that risk.

The contract damages question is difficult because it is hard to decide whether disappointed expectations are like nonphysical torts or whether they are rather like the more ethereal kinds of injury which we do not think deserve vindication in court.

The slavery question is difficult first and foremost because of the nonidentity problem, but also because of the thorniness of deciding which advantages of living in the United States ought to be offset against the damage claim, and because of the uncertain status of slavedescendants born after reparations payments have been made. 